Carina Olset

Journalist og programleder, NRK sport

Foto: Anne Liv Ekroll, NRK

\title{
Når skal man stole på legen sin?
}

\author{
Jeg skal ikke - og kan ikke - si noe \\ om hvorfor Therese Johaug og \\ legen hennes ikke sjekket pakning, \\ innholdsfortegnelse eller tube en \\ ekstra gang. Men jeg kan - og vil - \\ si noe om å stole på legen sin.
}

I 2011 fikk jeg diagnosen ulcerøs kolitt. En tullediagnose, trodde jeg. Plagene forsvant fort da jeg begynte å ta to såkalte 4ASA-tabletter hver dag. Det gikk fint helt til det ikke gikk fint lenger.

I 2014 fikk jeg en lege på sykehuset som skulle følge meg tett. La oss kalle ham Petter. Han var en ordentlig tullelege, en hedersbetegnelse, akkurat en sånn som jeg liker. Snakker rett fra levra, med humor og levende bilder, trygg og med enorm troverdighet. For første gang møtte jeg en lege som visste nøyaktig hva jeg slet med og nøyaktig hva jeg trengte. Han var streng når han måtte være streng, han var fintfølende da jeg lå på isolat og tryglet om å bli utskrevet 22. desember slik at jeg kunne rekke det siste flyet nordover til jul. Han har fulgt meg i tykt og tynt de siste årene. Helt siden det første møtet har jeg stolt blindt på ham og har stort sett gjort som han sier.

På et tidspunkt, før isolatet, hadde jeg utviklet antistoffer mot en biologisk medisin som hadde fantastisk virkning på meg. Dermed måtte vi finne på noe annet. Løsningen var en ny medisin, noen milde cellegifttabletter som skulle hindre meg i å utvikle antistoffer mot det nye medikamentet. Problemet var at medisinen gjorde meg enda verre, enda sykere, enda slappere. Den gjorde meg så syk at når jeg tenker på det, får jeg et smertefullt tomrom i magen. Jeg håper jeg aldri, aldri blir så dårlig igjen. Jeg var hos familien i Troms $\varnothing$ da den verste reaksjonen kom. Det var som om den sakte, men sikkert sugde livet ut av meg. Ingenting skulle inn. Alt skulle ut. Øyelokkene var blytunge, men prøvde jeg å legge meg, var det som om kroppen fikk konstant støt av å ligge på et underlag. Søsteren min laget havresuppe til meg for å gi meg krefter, men den fikk det til å eksplodere i kroppen - jeg tenkte at nå er jeg ved veis ende.

På sykehuset i Troms $\varnothing$ la de meg inn. Etter et tosifret antall stikk klarte de å få i meg en nål, og via den fikk jeg i meg noe som hjalp. Noe som fjernet kvalmen. Som fikk meg til å sove. Som fikk meg i stand til å spise en yoghurt. Legen sa at det var en klassisk reaksjon på medisinen. Og da jeg sluttet, ble jeg bedre time for time.

Men tilbake i Oslo, hos han Petter, viste blodprøvene at jeg tålte medisinen. Og da han sa at vi skulle prøve igjen, prøvde vi selvsagt igjen. Han er Min Beste Mann. Han er Legen min. Og han sa at jeg godt kunne ta bare én tablett, i stedet for to som sist. Det var noen måneder etter de dramatiske døgnene i Troms ø og jeg var på vei til svigerfamiliens hytte for å feire påske. To dager gikk det før jeg så døden i hvitøyet nok en gang. Overdramatisk ordbruk, kanskje? Vel, for meg føltes det sånn. Og jeg kan garantere at det var høydramatisk for svigermor da jeg måtte spy på grunn av frokosten hun hadde servert med kjærlighet. Jeg sendte en sms til han Petter og avsluttet behandlingen. Aldri igjen, sa jeg. Og jeg har fått viljen min.

Poenget med å fortelle dette er ikke at jeg aldri burde gjort som legen min sa. Poenget er at jeg jeg stoler blindt på han Petter. Jeg vet at han vil mitt beste. Jeg vet at han har spesialkompetanse. Jeg vet at han vet best.

l innholdsfortegnelsen til loperamid står det at man ikke skal bruke det hvis man har ulcerøs kolitt. Det samme står det i lbux-pakken. Det gikk noen år før jeg hadde hatt nok menssmerter og muskulære låsninger i ryggen til at jeg anså det som eneste utvei: Å spørre legen om jeg kanskje kunne bruke noe for å redusere det. Ta Ibux, svarte han. Det var også han som anbefalte meg å bruke loperamid ved stressende anledninger. Det har reddet meg gjennom veldig mange direktesendinger.

Sykehuslegen min svarer alltid når jeg sender sms. Han ringer for å spørre hvordan jeg har det hvis han ser at fekaltestene jeg leverer med jevne mellomrom er for høye. Han forteller meg om utviklingen på medisinfronten. Han sier ifra om han er borte fra jobb slik at jeg vet hvor jeg skal ringe om jeg trenger akutt hjelp. Og jeg gjør akkurat som han sier.

Bortsett fra når han vil sykmelde meg selv om jeg føler meg bra. Det har skjedd et par ganger, og da diskuterer vi litt. Men uansett hvem som får viljen sin, utsetter jeg meg ikke for annen risiko enn å gå på en litt forventet smell igjen.

En smell som tross alt er langt lettere å handtere enn en positiv dopingtest.

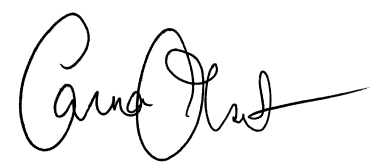

